TID-10062

\title{
THERMAL CONDUCTIVITY DATA FOR SOME NUCLEAR FUELS
}

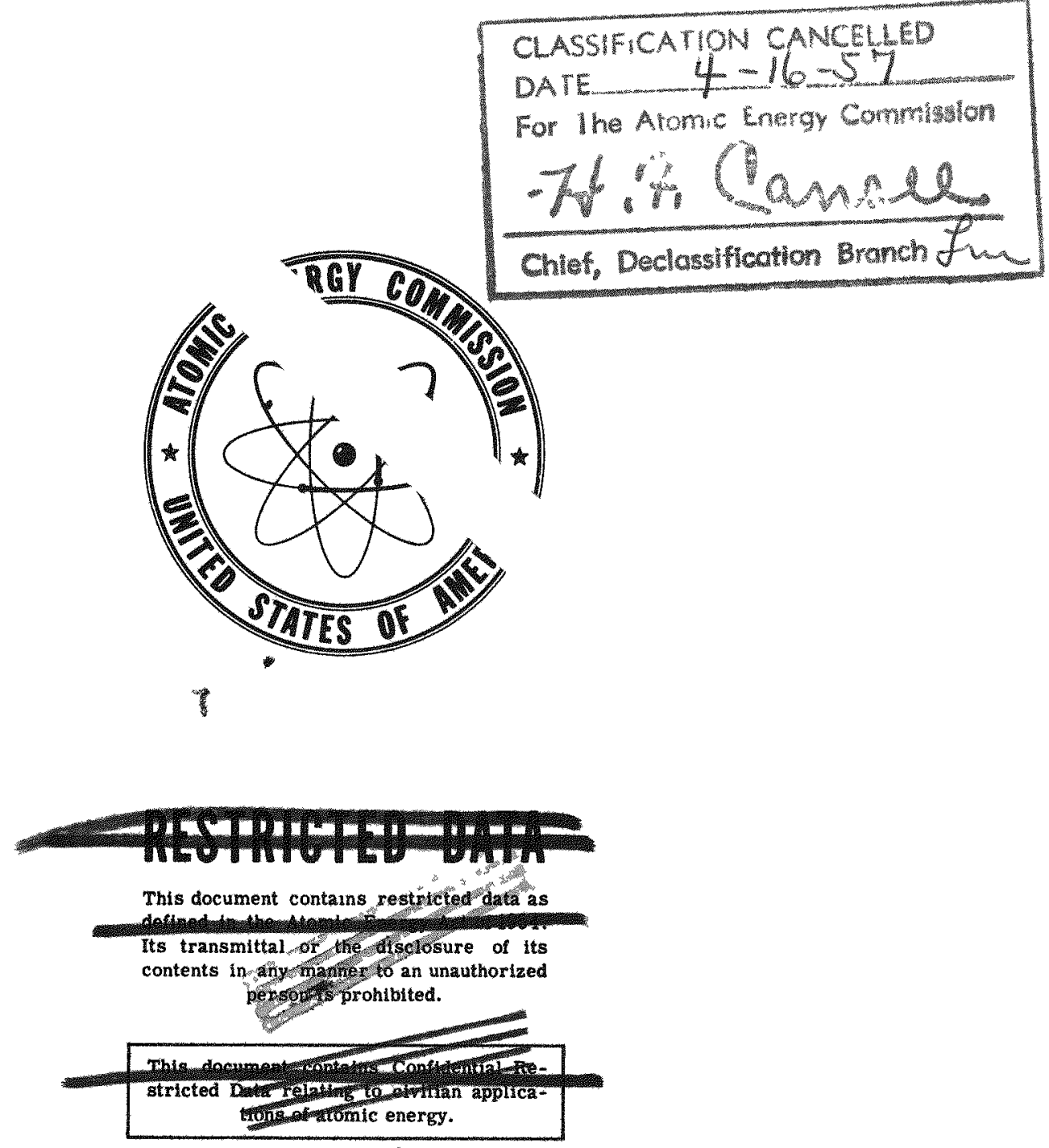

Technical Information Service, Oak Ridge, Tennessee

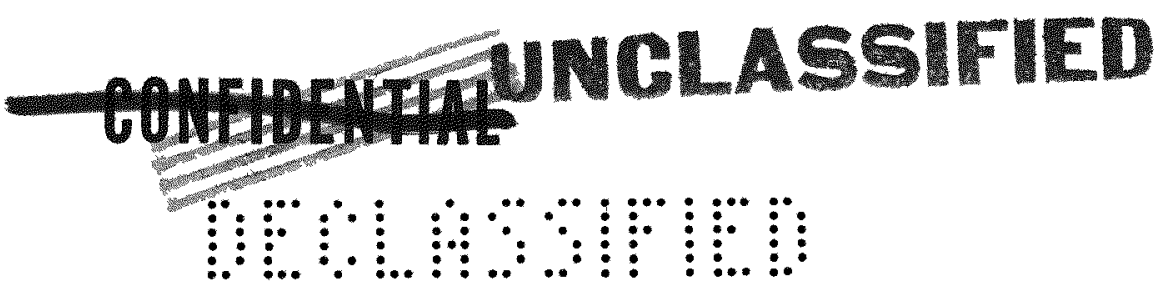




\section{DISCLAIMER}

This report was prepared as an account of work sponsored by an agency of the United States Government. Neither the United States Government nor any agency Thereof, nor any of their employees, makes any warranty, express or implied, or assumes any legal liability or responsibility for the accuracy, completeness, or usefulness of any information, apparatus, product, or process disclosed, or represents that its use would not infringe privately owned rights. Reference herein to any specific commercial product, process, or service by trade name, trademark, manufacturer, or otherwise does not necessarily constitute or imply its endorsement, recommendation, or favoring by the United States Government or any agency thereof. The views and opinions of authors expressed herein do not necessarily state or reflect those of the United States Government or any agency thereof. 


\section{DISCLAIMER}

Portions of this document may be illegible in electronic image products. Images are produced from the best available original document. 
Subject Category, METAIIURGY AND CRRAMICS.

This report has been reviewed under the Declassification Guide of 1955.

The Atomic Energy Commission makes r as to the accuracyor usefulness of the infor in this report, or that the use of any irt process disclosed in this report may $n$ The Commission assumes no llabilip. damages resulting from the use of, process disclosed in this report. susentation or warranty or statements confained on, apparatus, method or ige privately-owned rights. respect to the use of, or for vormation, apparatus, method or

This report has been reproduced directly from the best available copy.

Printed in USA, Chaxge 25 cents. Avallable from Technical Information Service, Induatrial Reports Section, P. 0. Box 1001, Oak Ridge, Tenn. Please direct to the same address inquiries covering the procurement of clabsified AFC reports.

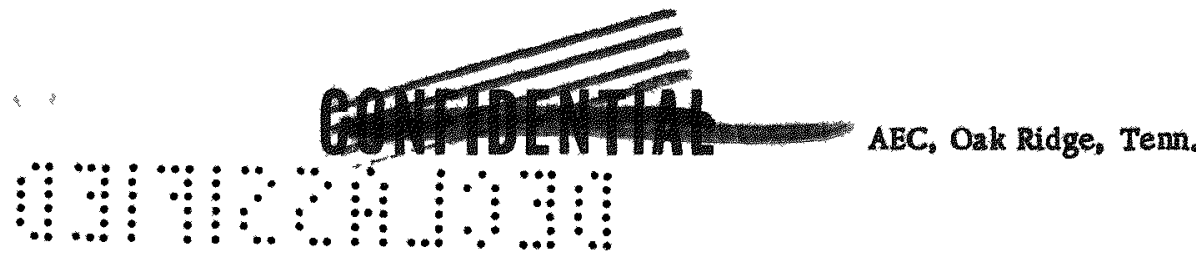


This report was prepared as an account of Government sponsored work. Neither the United States, nor the Commission, nor any person acting on behalf of the Commission:

A. Makes any warranty or representation, express or implied, with respect to the accuracy, completeness, or usefulness of the information contained in this report, or that the use of any information, apparatus, method, or process disclosed in this report may not infringe privately owned rights or

B. Assumes any liabilities with respect to the use of or for damages resulting from the use of any information, apparatus, method, or process disclosed in this report.

As used in the above, "person acting on behalf of the Commission" includes any amployee or contractor of the Commission to the extent that such employee or contractor prepares, handles or distributes, or provides access to, any information pursuant to his employment or contract with the Commission.

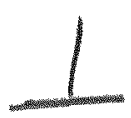

General Electric Company IRTOLIS ATOMIC POWER IABORATORY

Schenectady, New York

THERMAL CONDUCTIVITY DATA FOR SOME WUCLEAR FUELS

L. R. MeCreight

-

October 17,1952
Price $\$ 0.25$

Available from the

Office of Technical Services

Department of Commerce

Washington 25, D.C.

\section{ABSTRACT}

Thermal conductivity data for some mixtures of uranium dioxide with magnesium oxide, beryllium oxide, and zirconium; uranium vith zirconium and with magnesium; several samples of boron carbide; and two ceramic insulators ore presented.

Operated for the

United States Atomic Inergy Commission

by the

General Electric Company

Contract No. W-31-109 Ing-52 
CONIENTS

Page

Abstract .

Introduction

Specimens for Which Thermal Conductivity Values Were Determined . . . 6 Appendix . . . . . . . . . . . . . . . . . . . . . . 15

\section{LISI OF FIGURES}

Figure 1 (KH-9A2324) Thermal Conductivity of a Sintered MgO- $\mathrm{UO}_{2}$ Specimen

Figure 2 (KH-9A2325) Thermal Conductivity of Sintered BeO-UO2 Specimens

Figure 3 (KH-9A2326) Thermal Conductivity of Zirconium, ZirconiumUranium Alloys, and Zirconium-Uranium Oxide . 9

Figure 4 (KH-9A2327) Thermel Conductivity of Magnesium-Uranium and Magnesium Bxtruded Powder Specimens . . . 10

Figure 5 (KH-9A2328) Thermal Conductivity versus Temperature for Synthetic Mico . . . . . . . . . . Il

Figure 6 (KH-9A1493) Thermel Conductivity versus Temperature for $\mathrm{MgTiO}_{3}$ Porcelain Body . . . . . . 12

Figure 7 (KH-9A2329) Thermal Conductivity of Molded Boron Carbide at Various Densities . . . . . . . 13

Figure 8 (KH-9A2330) Thermel Conductivity versus Temperature for Sodium Sillcate Bonded Boron Carbide . . . 14

Figure 9 (K-6A3367) Thermal Conductivity Apparatus for Solid Specimens (MIT) . . . . . . . . . . 17

Figure 10 (K-6A3366) Thermel Coaductivity Apparatus for Powdered Specimens (MIT) . . . . . . . . . . . 18

Figure 11 (K-6A3368) Thermal Conductivity Apparatus for Powdered

$$
\begin{gathered}
\text { Specimens (NACA) } \\
\text { d let. }
\end{gathered}
$$


THERMAL CONDUCTIVITI DATA FOR SOME NUCLEAR FUELS

I. R. MeCreight

\section{IIMRODUCTION}

The thermal conductivity of a reactor fuel meterial is of prime importance in the calculation of heat flow and resultant centrol temperature of the lement. To determine the $\mathrm{K}$ values for some possible fuels, arrangement

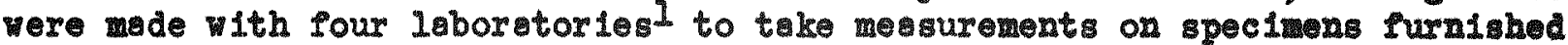
by KAPL. At the start of the program, the emphesis was on sintered ceramic fuels and diluents; however, this shifted to powdered fuel mixtures with varlous gaseous tmospheres. Several speclmens of boron carbide, ceralc electrical insulators, and metalilc ruels and diluents vere lo lncluded in the program.

This report $18 \mathrm{pr}$ inarily a progress report to present data obtained to date and a description of the spperatus being used. Dato on three of the boron carblde specimens which were obtalned by Battelle Memorial Institute have been published by them. 2 In addit10k, the work of the group at MACA 18 belng reported separetely. 3 " The nineter specimens for which reliable $K$ values vere obtalned are listed in the toble on the folloning page. References to the respective flgure number in which the curves are presented and the $\mathrm{K}$ value of each specimen $450^{\circ} \mathrm{C}$ are 180 given in the table. A brier deseription of the apparstus used by esch laboratory and pletoral draving of the specimen are presented in the appexdix.

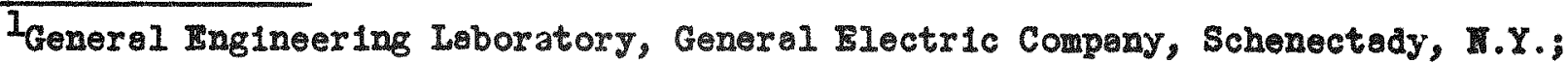
Battelle Memorial Inst1tuto, Columbus, Ohlo; Messachusetts Institute of pechnology, Cambridge, Mass.; National Adrisory Committee Por Aeronautics, Cleveland, Ohio.

¿ $\mathrm{BMI}-713$, "Thermel Conductivity of Boron Carblde from 100 to $800^{\circ} \mathrm{C}$, by H. Weem and C. Iucks.

3 WACA RM E52C05, "Investigation of Rffective Thermal Conduct1vities of Powders," by R. G. Delssler and C. S. Elen.

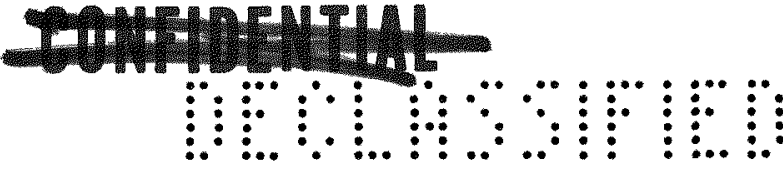


SPECIMENS FOR WEICH THERMAL CONDUCT IVITY VALUES WERE DETERMINED

\begin{tabular}{|c|c|c|c|}
\hline $\begin{array}{l}\text { Specimen Composition } \\
\text { (by wt.) }\end{array}$ & $\begin{array}{l}\text { Density } g / c c \\
\text { or \% of Theo. }\end{array}$ & Figure No. & $\begin{array}{r}\text { I at } 450^{\circ} \mathrm{C} \\
\text { watts } \cdot \mathrm{cm}^{-2} \cdot \mathrm{cm}^{\circ}{ }^{\circ} \mathrm{C}^{-1} \\
\end{array}$ \\
\hline \multicolumn{4}{|l|}{ Sintered Ceramics } \\
\hline $47 \% \mathrm{vO}_{2}-53 \% \mathrm{MgO}$ & $87.0 \%$ & 1 & 0.08 \\
\hline $70.9 \% \mathrm{UO}_{2}-29.1 \% \mathrm{BeO}$ & $80.5 \%$ & 2 & 0.27 \\
\hline $70.9 \% \mathrm{UO}_{2}-29.1 \% \mathrm{BeO}$ & $79.5 \%$ & 2 & 0.23 \\
\hline $47 \% \mathrm{OO}_{2}-53 \% \mathrm{BeO}$ & $71.2 \%$ & 2 & 0.20 \\
\hline $47 \% \mathrm{NO}_{2}-53 \% \mathrm{BeO}$ & $80.0 \%$ & 2 & 0.24 \\
\hline $43 \% \mathrm{UO}_{2}-57 \% \mathrm{Zx}$ & $59.0 \%$ & 3 & 0.10 \\
\hline \multicolumn{4}{|l|}{ Metals } \\
\hline Bureau of Mines $\mathrm{Zr}$ & $98-100 \%$ & 3 & 0.18 \\
\hline $29.7 \% 0-70.3 \% \mathrm{Zx}$ & $98-100 \%$ & 3 & 0.13 \\
\hline Extruded Magnesium & $98-100 \%$ & 4 & 1.33 \\
\hline Extruded $73.5 \% \mathrm{U}-26.5 \% \mathrm{Mg}$ & $98-100 \%$ & 4 & 1.09 \\
\hline \multicolumn{4}{|l|}{ Miscellaneous Materials } \\
\hline Synthetic Mica & $98 \%$ & 5 & 0.023 \\
\hline $\begin{array}{l}\text { Magnesium Titanate Porcelain } \\
\text { Boron Carbide }\end{array}$ & $2.87 \mathrm{~g} / \mathrm{cc}$ & 6 & 0.187 \\
\hline Hot-pressed & 2.5 & 7 & 0.19 \\
\hline Hot-pressed & 2.33 & 7 & 0.18 \\
\hline Rammed and sintered & 1.91 & 7 & 0.175 \\
\hline Rammed and sintered & 1.9 & 7 & 0.12 \\
\hline $\begin{array}{l}\text { Rammed with sodium silicate } \\
\text { binder }\end{array}$ & 2.06 & 8 & 0.126 \\
\hline $\begin{array}{l}\text { Rammed with sodium silicate } \\
\text { binder }\end{array}$ & 2.03 & 8 & 0.122 \\
\hline $\begin{array}{l}\text { Remmed with sodium sllicate } \\
\text { binder }\end{array}$ & 2.06 & 8 & 0.118 \\
\hline
\end{tabular}




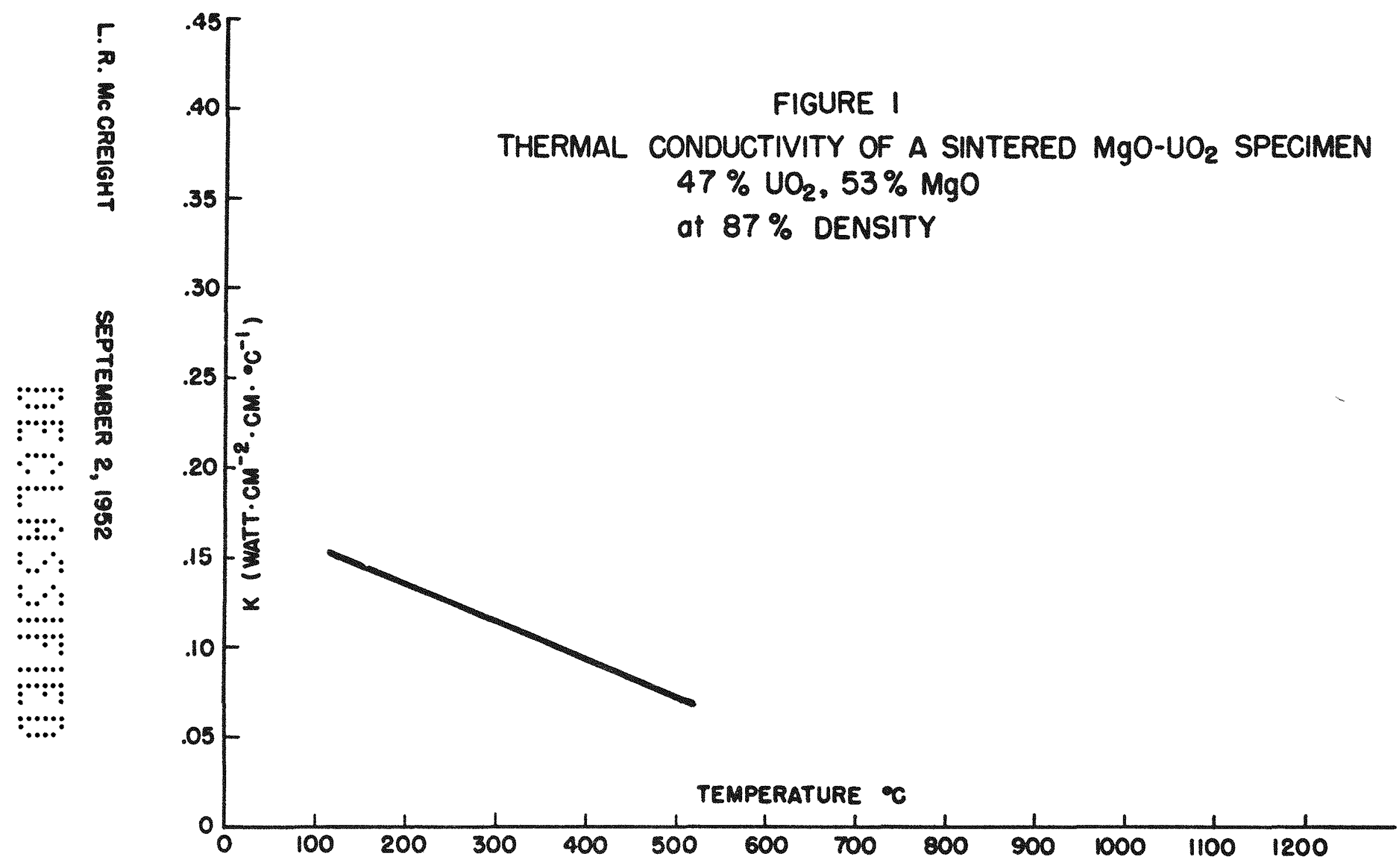




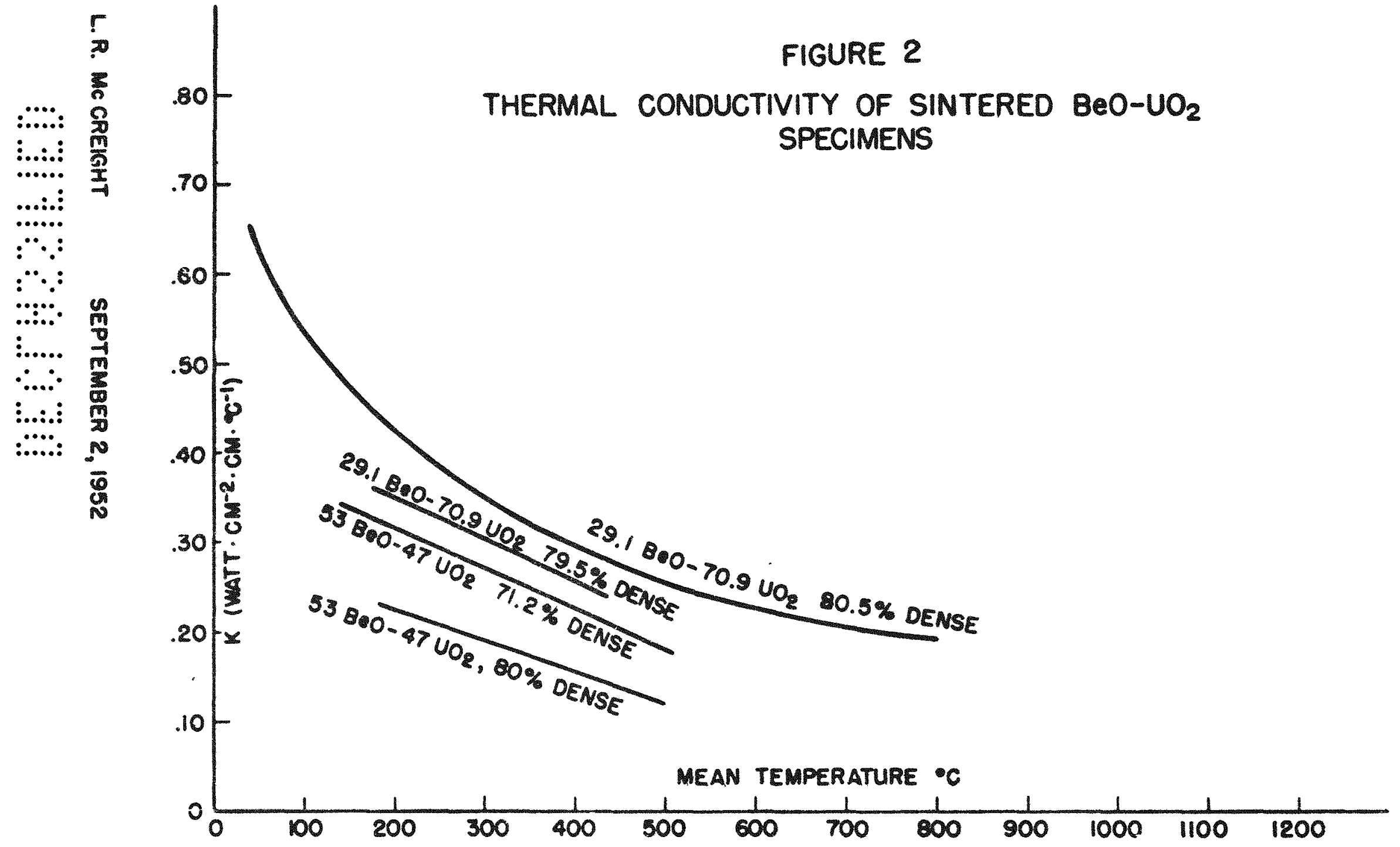




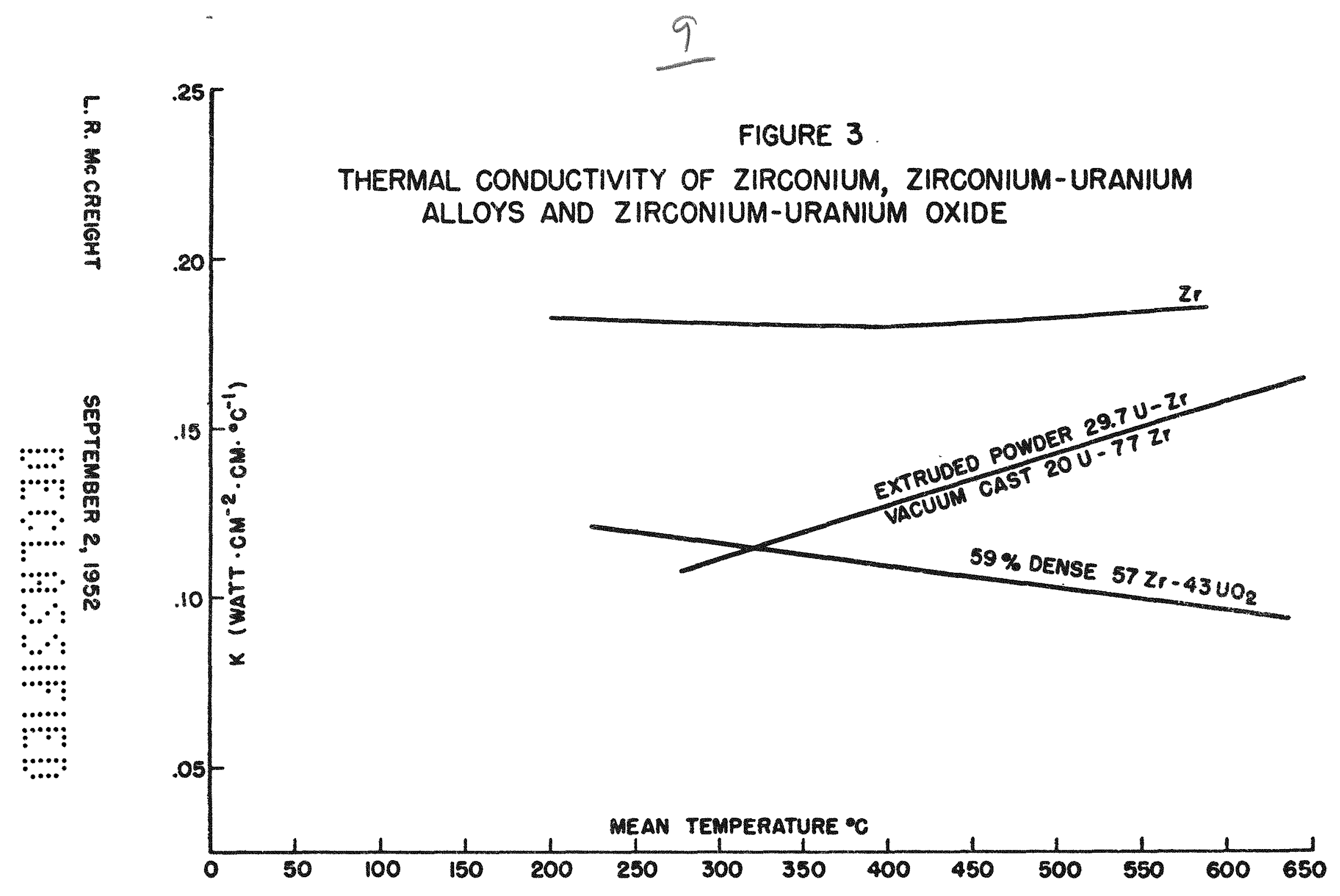




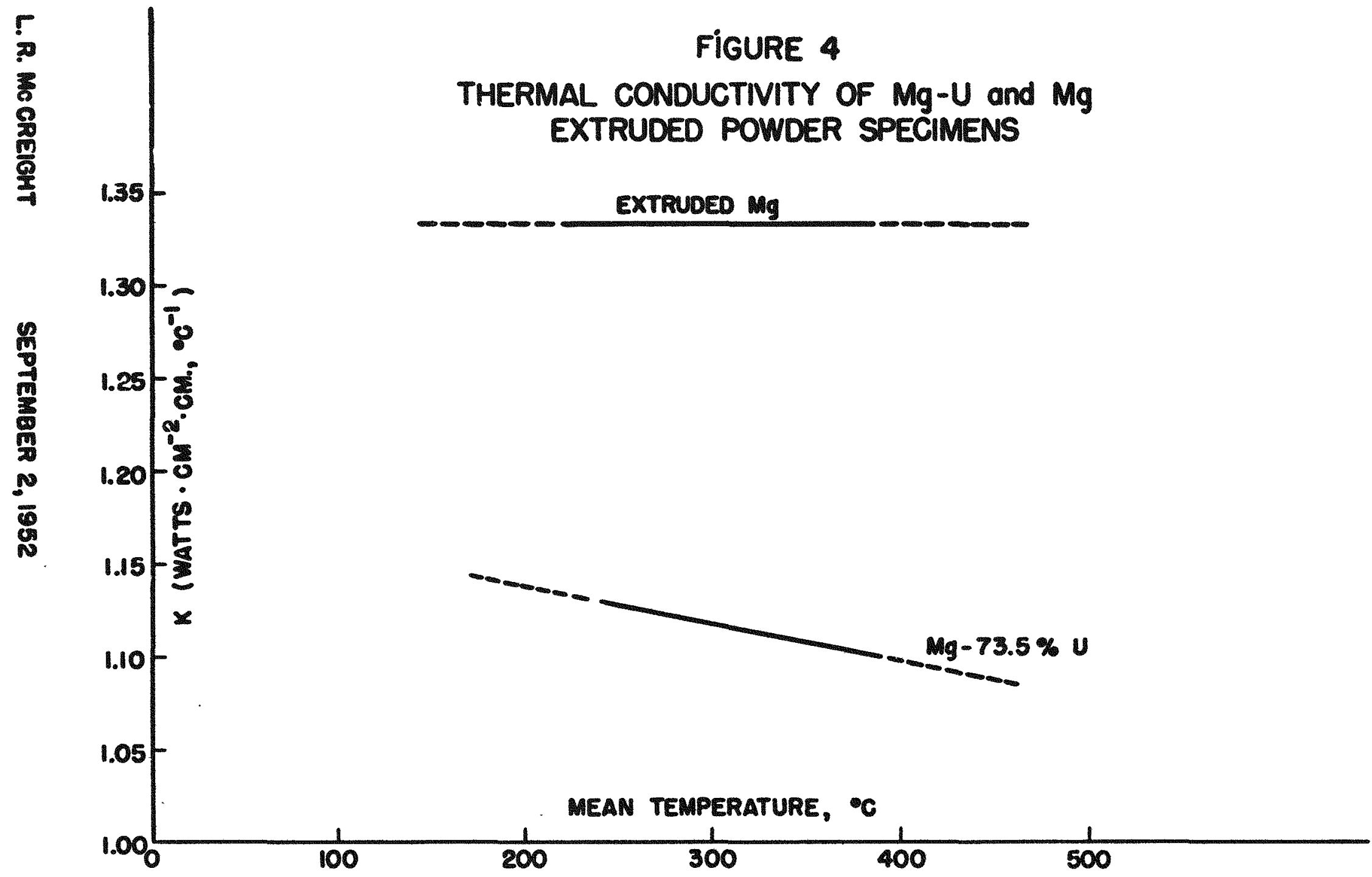


$r$
$\frac{5}{3}$
$\frac{5}{2}$
0
8
$\frac{1}{9}$
$\frac{9}{2}$

FIGURE 5

THERMAL CONDUCTIVITY VS. TEMPERATURE FOR SYNTHETIC MICA

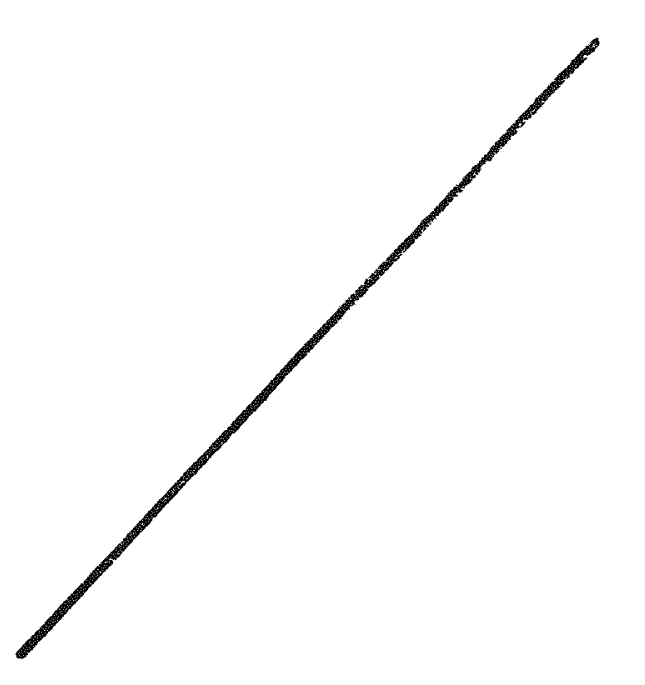

MEAN TEMPERATURE - $C$

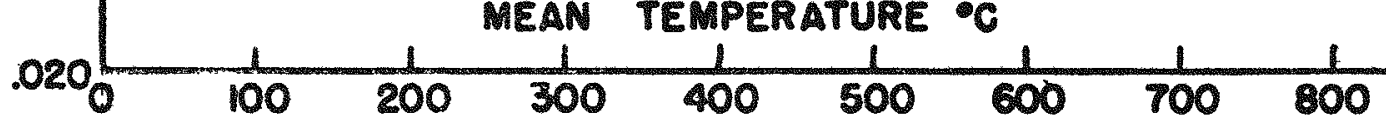




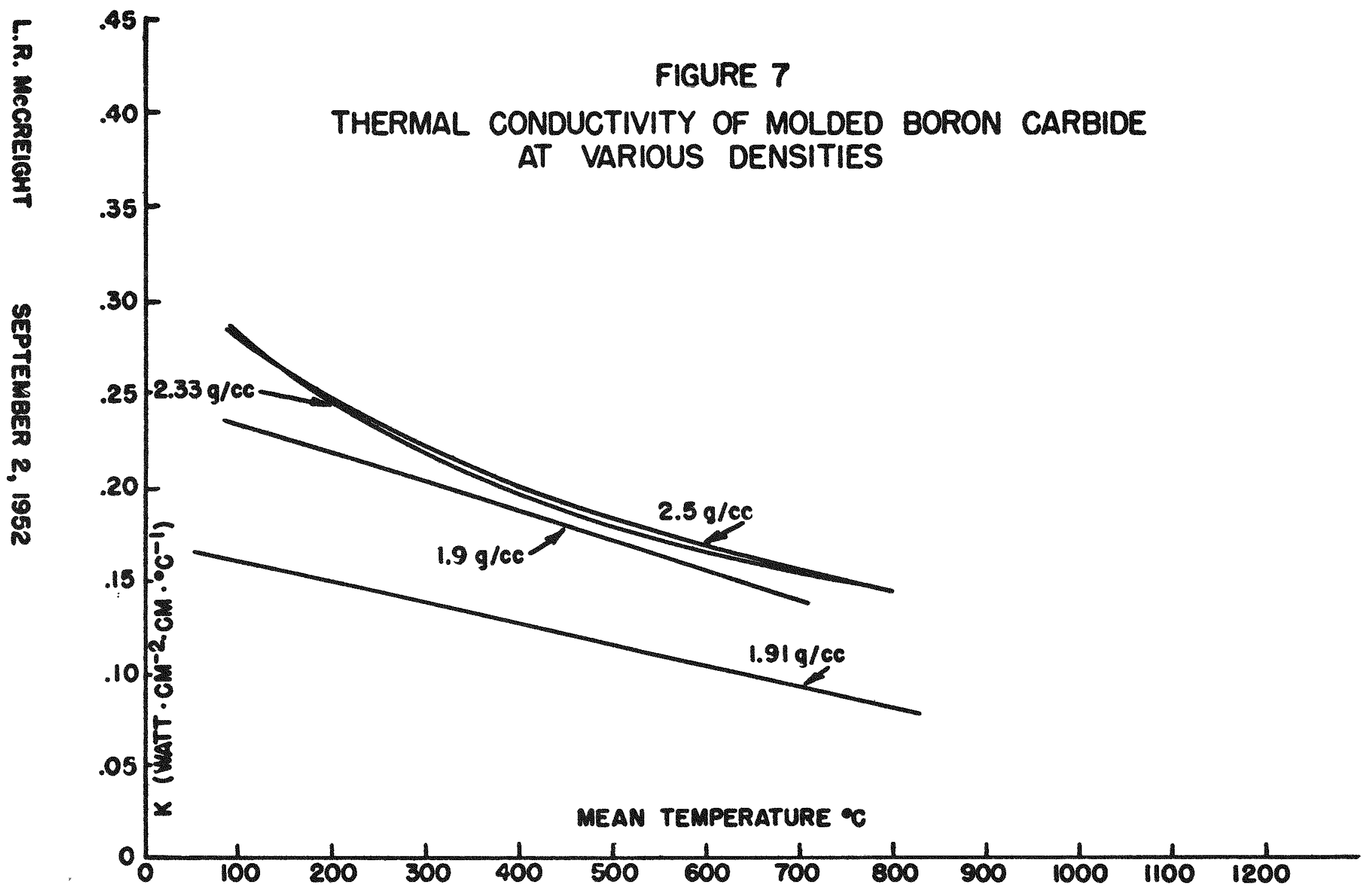




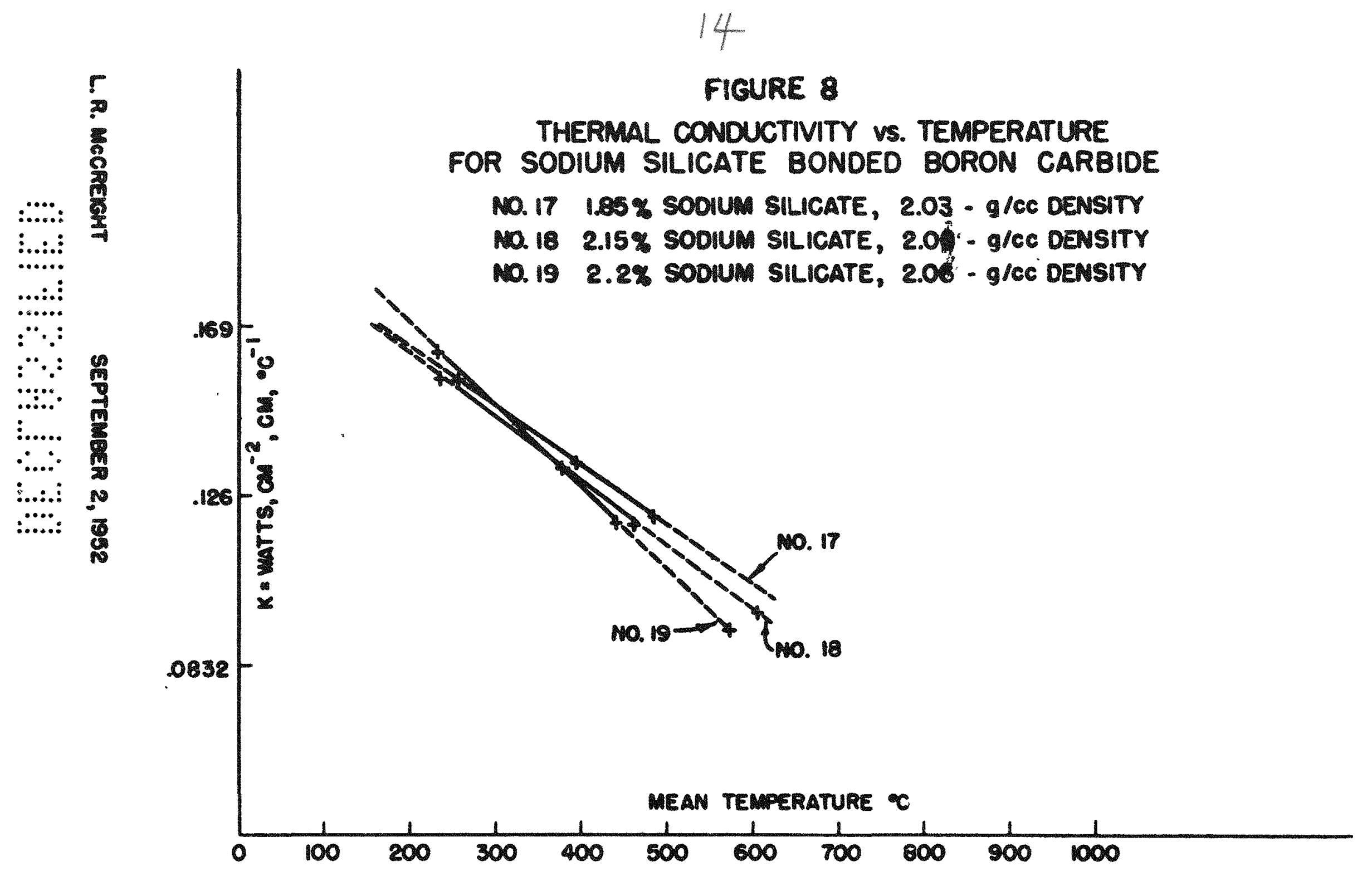




\section{APPENDIX}

The thermal conductivity epparatus used by each laboratory is briefly described below.

1. The General Ingineering Laboratory and Battelle Memorial Institute have each based their designs on the comparative method apparatus described by Van Dusen and Shelton. L The former laboratory uses $3 / 4$ inch diameter by 9 inch long specimen while the latter uses a $2 \mathrm{~cm}$ diameter by $6 \mathrm{~cm}$ long specimen. In both cases five thermocouples are cemented onto the specimen, at appropriate intervals, with the bead in small shallow holes. The atmosphere in the furnaces is usually air, however, some improvement is mode by flushing the spece with on inert gas to prevent or minimize the oxidation of uranium.

2. At the Massachusetts Institute of Technology, Professor W11kes constructed a special apparatus to determine thermal conductivity of $3 / 4$ inch diameter by 9 lnch long bars of material in either a vacuum or special atmosphere. The specimen, guard tube, water colorimeters, and heater arrangement are shown in Figure 9. This unit is mounted in a large vacuum tank which is in turn mounted in a tank of water. This opparatus provides good protection from oxidation of specimens containing uranium. Specimen temperature measurement is provided by three butt-welded thermocouples mounted in 0.030 inch holes drilled perpendicularly through the axis of the specimen.

A second test apparatus was also built by Prof. Wilkes for measuring the conductivity of gas-powder systems. The specimen and heater are shown in Figure 10. These are mounted in a sheet metal cylinder in which the remaining space is filled with insulation. It was found, however, that insufficlent gas pressure could be applied to the system for it to reach the optimum $K$ value as predicted by Austin's equation:?

$$
\begin{aligned}
K & =K_{g}(3 / \rho-1) \\
K & =\text { Overmall conductivity } \\
K_{g} & =\text { Conductivity of the gas } \\
p & =\text { Void volume of the powder }
\end{aligned}
$$

This portion of the work was then discontinued, since NACA was already constructing a high pressure tank for such measurements.

IVan Dusen, M. S., and Shelton, S. M., "Apparatus for Measuring Thermal Conductivity of Metals up to $600^{\circ} \mathrm{C}$," Journal of Research, National Bureau of Standards, Vol. I2. (R.P. 668, 1934, pp. 429-440).

${ }^{2}$ Symposium on Thermal Insulating Materials, ASTM, March 8, 1939, pp. 3-67. 
3. The Nationel Advisory Committe for Aeroneutics group at Lew is Flight Propulsion Laboratory designed and bullt the specimens shown in Flgure 11 which were filled at KAPL with ceramic powders. These specimens are mounted in a double-walled pressure tank where cooling water can flow between the walls. The full details of their apparatus and first tests are presented in IACA RM I52C05 so will not be repeated here. 


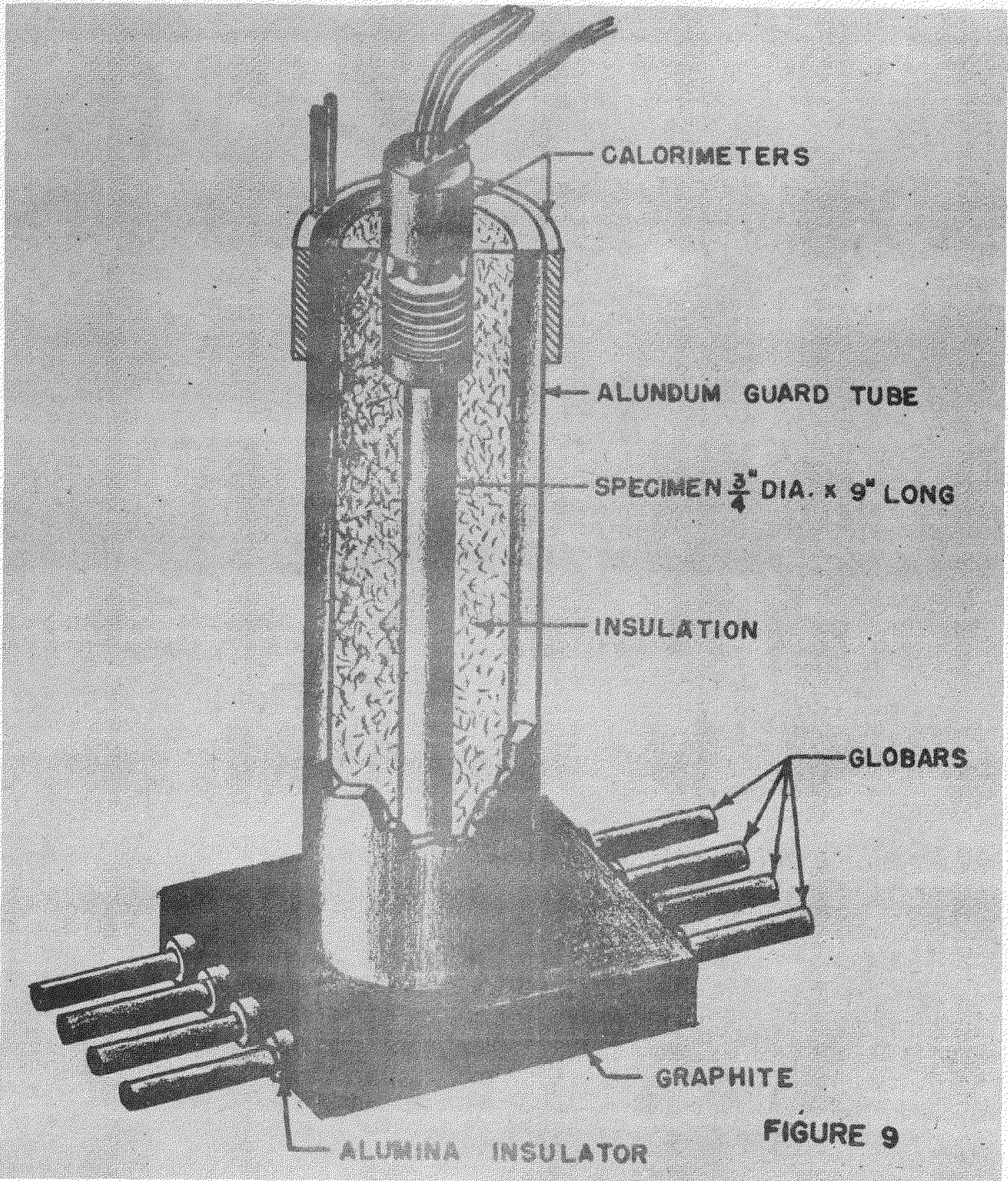




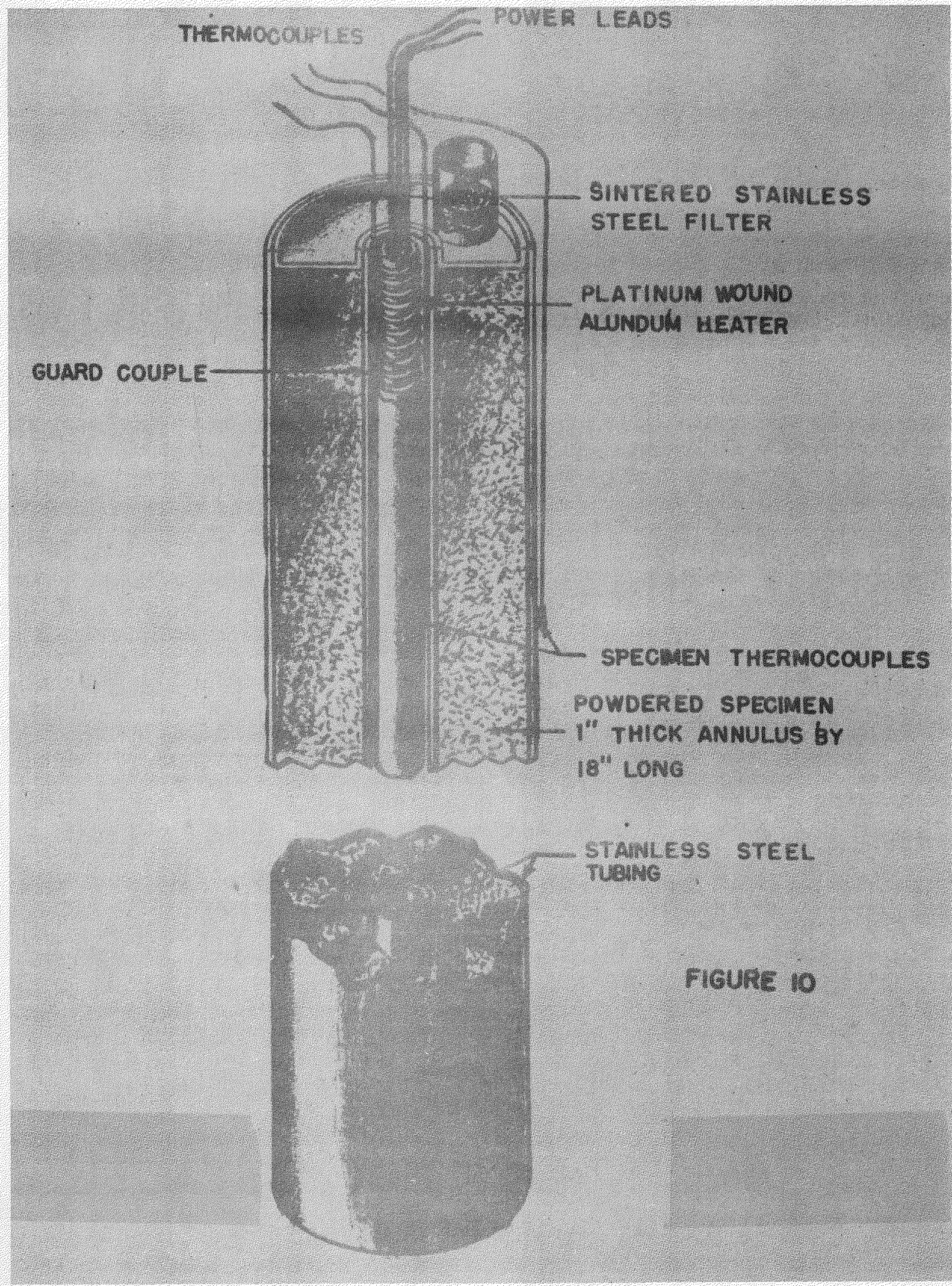




\section{GONFIDENTHAL}

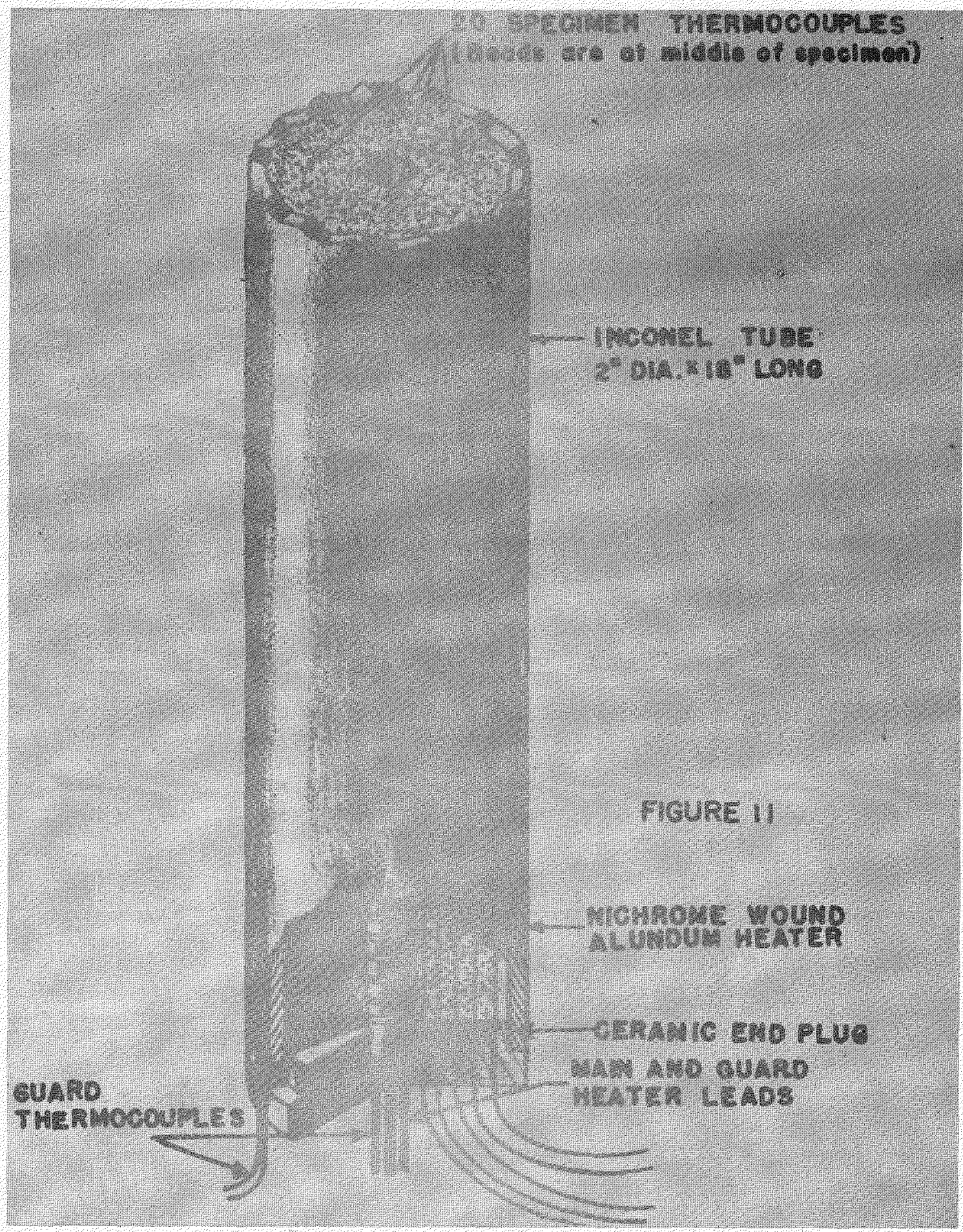

CONFIDENTIAL

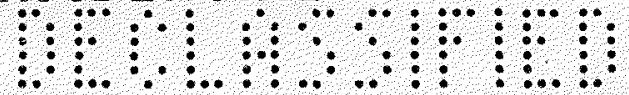

